第 20 群

\section{6 ヒト胎児における内耳の発生学的観察}

○斉藤龍介, 谷 互, 近藤 楥*

（岡山大，*岡山鉄道病院）

\section{7 世の犬のコルチ器における 蓋膜の石灰 沈着}

○折田洋造

（川崎医大）
98 内耳放射状細動脈に対するアルコンンー ザー照射による蝸牛の組織学的変化

吉川由絵, O佐々木浩, 小野泰三郎, 荻野洋一 （聖マリアンナ医大）

99 モルモットのコルチ器内電位について

O中島恒彦，山本哲生*

(九大, *福岡大)

\section{0 蝸電図による難聴の検討}

○棚橋汀路, 丹羽英人

(名大分院)
日本人胎児を用いて膜迷路の初期発生を組䄉学的に検 索した。内耳各部の解剖学的構造の分化発達ととすに endolymphatic sac and duct の分化拉よび喵媨神経と 内耳感覚上皮との連絡の 2 点について形態学的観察を行 い, 次の結果を得た。1) endolymphatic sac and duct は発生学的に 3 部炕区別しうる。2) 神経支配が感覚上皮 の分化に先行する。3)胎生11週までに膜迷路は外形の分 化招よび各感覚上皮の細胞学的分化をほぼ完成する。

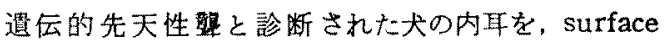

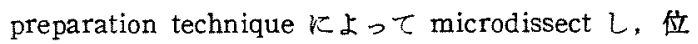

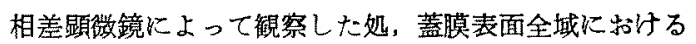
藷明な石灰沈着を見出した。

この新知見は内耳研究に surface preparation を応 用する事によって初めて見出されたものであり，又，同 時に観察された血管条の菱縮, 及び，Reissner 氏膜の 蓋膜一の附着, 更に毛細胞領域の洀痕化等之関聯して聴 覚喪失に重要な意味を有すると考学られる。

モルモントの䗁牛前庭階上骨壁にアルゴンレーザーを 照射して，放射状細動脈を選択的に損賃せしめ，内耳の

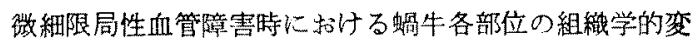
化を检索した。

正常な聴力のモルモット，およびカナマイシンによる 憼モルモットなどについて主としてコルチ器内電位括よ び組稢学的所見について检討してみた。トンネル内でる 陰性電位を認めうるようであり，コルチ器の䉓位が紐胞 内電位であるかど5かについてはな和考慮が必要であ る。

蛸牛電気現象のうち, CM, AP を誘導し, 聴力测定 を行ら螖電图聴力検査は末梢聴覚での病態生理を知るの に極めて有力な方法である。我なはこの妱電图法によっ 下聴力検查を行った。各症例共 CM, AP を測定し出力 波形と音任出力曲線で検討した。突発性難聴では $\mathrm{CM}$ ， AP 共に出力低下，CM に比し AP より高度の低下，聴 神経腫場ガルサン症候群等では AP 低下が双られた。 延䯣障害では CM, AP 共に正常に近い。また $\mathrm{CM}, \mathrm{AP}$ 誘導部位々測定音周波数について検討を加兄た。 